\title{
A STUDY ON GAP-ACCEPTANCE OF UNSIGNALIZED INTERSECTION UNDER MIXED TRAFFIC CONDITIONS
}

\author{
S.Siva Gowri Prasad ${ }^{1}$, Ramesh Surisetty ${ }^{2}$, Suresh Kumar ch $^{3}$ \\ ${ }^{1}$ Assistant professor, Department, of Civil Engineering, GMRIT, Rajam, A.P India \\ ${ }^{2}$ Post graduate student, Department of Civil Engineering, GMRIT, Rajam A.P India \\ ${ }^{3}$ Post graduate student, Department of Civil Engineering, GMRIT, Rajam A.P India
}

\begin{abstract}
Unsignalized intersections are the key elements in urban streets and in rural road networks. The methodology for the analysis of unsignalized intersections has been established where homogeneous traffic conditions are dominated, there are several attempts made to develop different approaches for the analysis of unsignalized intersections under mixed traffic conditions. Conflict technique is a recent development, which is based on pragmatically simplified concept, considering interaction and impact between flows at intersection. In present study, capacity of unsignalized intersection was calculated from Conflict technique. Surveys were conducted in Visakhapatnam, to measure different traffic parameters such as volume, flow \$ capacity to this method. Movements of capacity were evaluated by HCM (2000) by comparison with approach wise capacities obtained from conflict technique.
\end{abstract}

Keywords: Unsignalized Intersection, Surveys, Traffic Parameters, Tanner's Model, Capacity, Conflict technique. $* * *$

\section{INTRODUCTION}

An intersection is a node, and usually it is a block of traffic flow in highway network. Capacity of a intersection affects the total capacity of highway network due to all types of turning movements. For actions of conflicting, merging and diverging caused by traffic flow, the traffic characteristics of intersection are more complex than those of road mid block section. Traffic stream in developing countries comprises of different types of motorized and non-motorized vehicles leads to mixed traffic conditions and lane changing patterns.

Urban roads in India carry different types of vehicles like high speed automobiles, low speed cycles, cycle rickshaws and animal drawn carts. This will lead to complex interaction between the vehicles and study of such traffic behavior needs special attention. The traffic plying on roads in western countries is of characteristics of different vehicles with marginal variation contrary to large variation on Indian roads. This will result in increased interactions between vehicles; then they tend to move in clusters rather than one after the other. Further two or three wheelers such as scooters, cycles, and cycle rickshaws contribute to this because of their easy maneuverability.

The traffic on Indian roads consists of bi-directional freedom traffic such as two or three wheeled vehicles and uni-directional vehicles such as four wheelers. While the above tend to overtake or turning or crossing or turn right even if a small gap is available. Hence, to determine the intersection capacity traffic engineer requires a clear understanding of gaps being accepted or rejected by various modes of traffic. Besides, in these mixed traffic conditions, users do not usually follow lane discipline and can occupy any lateral position on the road. Under these conditions, capacity of an unsignalized intersection is difficult to be determined and becomes a very interesting field of highway capacity study. There are several types of capacity analysis models for unsignalized intersections. The third approach is the conflict technique which was based on the mathematical formulation of interaction and impact between flows at an intersection.

Aldian et.al (2001) [1] examined the suitability of some traffic models to determine U-turn capacity at median openings. Ian C. Espada et.al (2002) [2] deals with the development of a priority intersection Capacity Formula that is sensitive to control type. Ning WU (1999) [3] performed a simplest configuration with one Major stream and one Minor stream and a new universal capacity formula is introduced. Tian et.al (1999) [4] showed that most of the capacity calculation procedures for two-way stop-controlled (TWSC) intersections are based on gap acceptance models. Wan Hashim et.al (2007) [6] showed that Critical Gap Acceptance procedure is still widely used for estimating capacity of unsignalized intersection. Werner Brilon et.al (1996) [7] deals with the capacity of minor traffic movements across major divided four-lane roadways (also other roads with two separate carriageways) at unsignalized intersections. Werner Brilon et.al (1997) [8] has performed a series of comprehensive simulations of some of the estimation methods.

\subsection{Objectives}

- To study the different traffic parameters for conflict technique by using HCM method.

- To identify the traffic conflicts in major \& minor streams in a particular intersection/junction. 
- To know the priorities an intersection/junction by using Mathematical Model.

\subsection{Study Area}

The major traffic conflicts occur at T-Intersections are identified in Visakhapatnam:

- Urvasi Junction

- Kancharpalem Junction

- Gnanapuram Junction

Figures 1, 6 and 11 shows the pictorial representation of three Junctions

\section{DATA COLLECTION}

The study of traffic behaviour is useful for traffic engineers to design intersections, for developing traffic control warrants, traffic signal timings, to design the vehicle storage lanes. Data is needed for analysis and understanding of the traffic conditions. The data can be collected by manual method.

\subsection{Requirements}

The main objective of this study is to find the capacity of unsignalized intersection using conflict technique and to compare the results with the HCM (2000) procedure, which is based on the gap acceptance procedure. For this the following field observations are necessary.

- Travelled distance for each movement on each approach.

- Times of arrival and departure at reference lines for each vehicle from each stream.

- Approach speed of the vehicles.

- Volume at unsignalized intersection movementwise.

Manual counts are typically used to gather data about the following:

- Vehicle classifications

- Turning movements

- Direction of travel

- Pedestrian movements

- Vehicle occupancy

The number of people need to collect data depends on the length of the count period, type of data being collected, number of lanes or cross walks being observed, and traffic volume.

\subsection{Volume Count Study (Straight Road Stretch)}

To determine the number, movement and classification of roadway vehicles at a given location. The number of observers needed to count the vehicles depends upon the number of lanes in the highway on which the count is to be taken and the type of information desired. The indications in table can be used as rough guides. It is perhaps more desirable to record traffic in each of travel separately and past separate observer for each direction enumerators should be literate persons with preferably middle or matriculation level for the purpose.

This survey has been conducted at Urvasi, Kancharpalem and Gnanapuram of T-Intersections.

\subsection{Volume Count Study (An Intersection)}

To determine the number, movement and classification of roadway vehicles at an intersection. Traffic volume studies are conducted to determine the number of movements and classification of roadway vehicles at a given location. These data can help identifying critical flow time periods, determine the influence of large vehicles or pedestrians on vehicular traffic flow or document traffic volume trends. The length of the sampling period depends on the type of count being taken and the intended use of the data recorded. For manual count, $15 \mathrm{~min}$ interval could be used to obtain the traffic volume data.

This survey has been conducted at Urvasi, Kancharpalem and Gnanapuram of T-Intersections.

\subsection{Gap Acceptance Study}

Pedestrians preparing to cross the roadway must access the gaps in conflicting traffic determine whether sufficient length is available for crossing and decide to cross the road. Following experiments presents a method for collecting field data to identify the minimum usable gap. As if any traffic engineering analysis recognition and definition of the difference between the standard values and the observed values, the observed values increase the accuracy.

This survey has been conducted at Urvasi, Kancharpalem and Gnanapuram of T-Intersections.

\subsection{Gap Acceptance Capacity Model}

The theory of gap-acceptance is the major concept for unsignalized intersection analysis. This method is based on critical gap acceptance and follow up times of vehicles from the minor road.

The modified Tanner's formula was found to be the most suitable model. Tanner proposed a theoretical model to relate the various parameters connected with the delay problem in dealing with an Intersection of a Major and Minor road and for finding capacity at unsignalized intersections and the expression is as follows:

$$
C_{p}=\frac{q_{M}\left(1-\lambda t_{p}\right) e^{-\lambda\left(t_{c}-t_{p}\right)}}{1-e^{-\lambda t_{f}}}
$$

Where,

$\lambda=\mathrm{q}_{\mathrm{M}} / 3600(\mathrm{veh} / \mathrm{s})$

$\mathrm{t}_{\mathrm{p}}=$ minimum headway in the major traffic stream

$\mathrm{t}_{\mathrm{c}}=$ critical gap

$\mathrm{q}_{\mathrm{M}}=$ number of major stream headways

$\mathrm{t}_{\mathrm{f}=\text { follow-up gap respectively }}$ 


\subsubsection{Tables and Figures}

1) Table 1 and 2 shows the maximum No. of Vehicles and maximum Capacity Time in the study area for $1^{\text {st }}$ and $2^{\text {nd }}$ hours at Urvasi Junction.

2) Table 3 and 4 shows the maximum No. of Vehicles and maximum Capacity Time in the study area for $1^{\text {st }}$ and $2^{\text {nd }}$ hour at Kancharpalem Junction.

3) Table 5 and 6 shows the maximum No. of Vehicles and maximum Capacity Time in the study area for $1^{\text {st }}$ and $2^{\text {nd }}$ hour at Gnanapuram Junction.

4) Figures 2, 4, 7, 9, 12, 14 show the graphs for maximum No. of Vehicles in the study area of $1^{\text {st }}$ and $2^{\text {nd }}$ hour.

5) Figures 3, 5, 8, 10, 13, 15 show the graphs for maximum Capacity Time (Min) in the study area of $1^{\text {st }}$ and $2^{\text {nd }}$ hour.

Table-1: Hourly Traffic in Morning Peak Hours at Urvasi Junction

\begin{tabular}{|l|l|l|l|l|}
\hline \multirow{2}{*}{ Conflict } & \multicolumn{2}{|l|}{ No. of Vehicles } & \multicolumn{2}{l|}{$\begin{array}{l}\text { Maximum } \\
\text { Capacity }\end{array}$} \\
\cline { 2 - 5 } & $\begin{array}{l}\text { 1st } \\
\text { Hour }\end{array}$ & $\begin{array}{l}\text { 2nd } \\
\text { Hour }\end{array}$ & $\begin{array}{l}\text { 1st } \\
\text { Hour }\end{array}$ & $\begin{array}{l}\text { 2nd } \\
\text { Hour }\end{array}$ \\
\hline $\begin{array}{l}\text { Towards } \\
\text { Complex }\end{array}$ & 184 & 190 & 41.86 & 22.28 \\
\hline Left side & 176 & 182 & 32.56 & 30.6 \\
\hline $\begin{array}{l}\text { Away from } \\
\text { Complex }\end{array}$ & 183 & 187 & 26.34 & 20.49 \\
\hline Right side & 196 & 200 & 25.95 & 20.79 \\
\hline
\end{tabular}

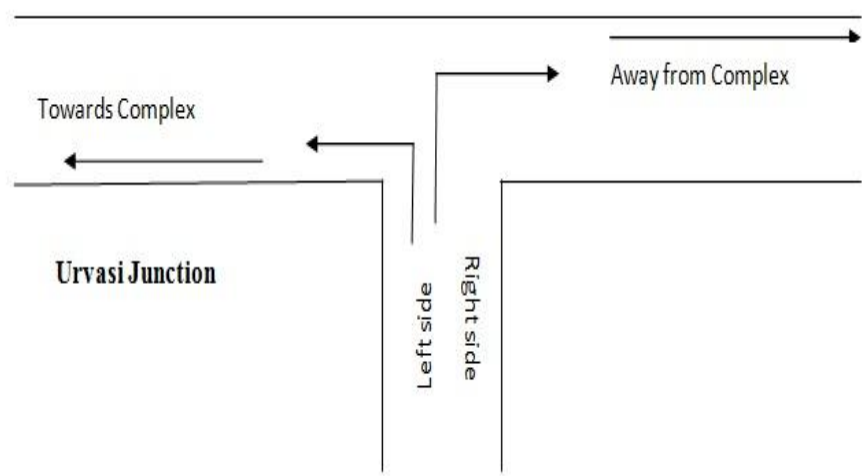

Fig-1: Urvasi Junction

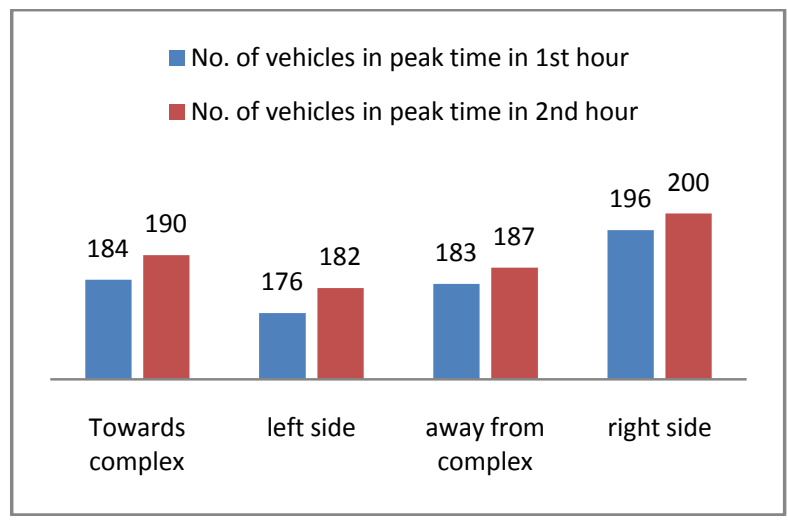

Fig-2: No. of Vehicles in Morning Peak Hours

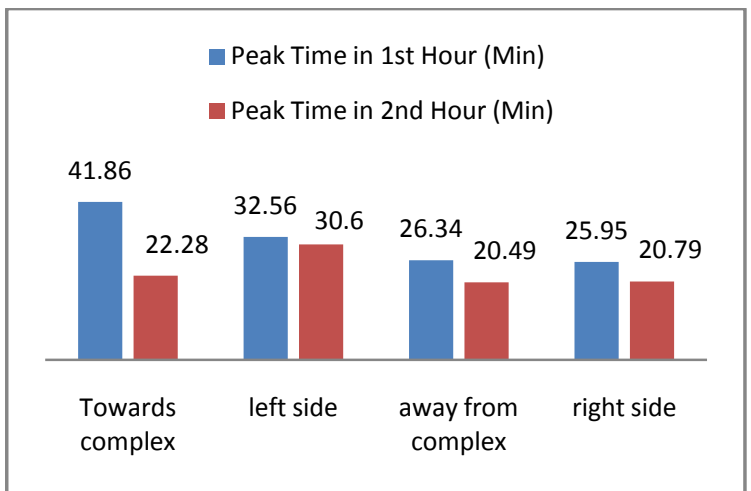

Fig-3: Hourly variations of Time (Min)

Table-2: Hourly Traffic in Evening Peak Hours at Urvasi Junction

\begin{tabular}{|l|l|l|l|l|}
\hline \multirow{2}{*}{ Conflict } & \multicolumn{2}{|l|}{$\begin{array}{l}\text { No. of } \\
\text { Vehicles }\end{array}$} & \multicolumn{2}{l|}{$\begin{array}{l}\text { Maximum } \\
\text { Capacity }\end{array}$} \\
\cline { 2 - 6 } & $\begin{array}{l}\text { 1st } \\
\text { Hour }\end{array}$ & $\begin{array}{l}\text { 2nd } \\
\text { Hour }\end{array}$ & $\begin{array}{l}\text { 1st } \\
\text { Hour }\end{array}$ & $\begin{array}{l}\text { 2nd } \\
\text { Hour }\end{array}$ \\
\hline $\begin{array}{l}\text { Towards } \\
\text { Complex }\end{array}$ & 189 & 178 & 58.07 & 34.63 \\
\hline Left side & 191 & 190 & 53.07 & 43.3 \\
\hline $\begin{array}{l}\text { Away from } \\
\text { Complex }\end{array}$ & 192 & 200 & 53.1 & 48.29 \\
\hline Right side & 169 & 189 & 51.8 & 46.1 \\
\hline
\end{tabular}

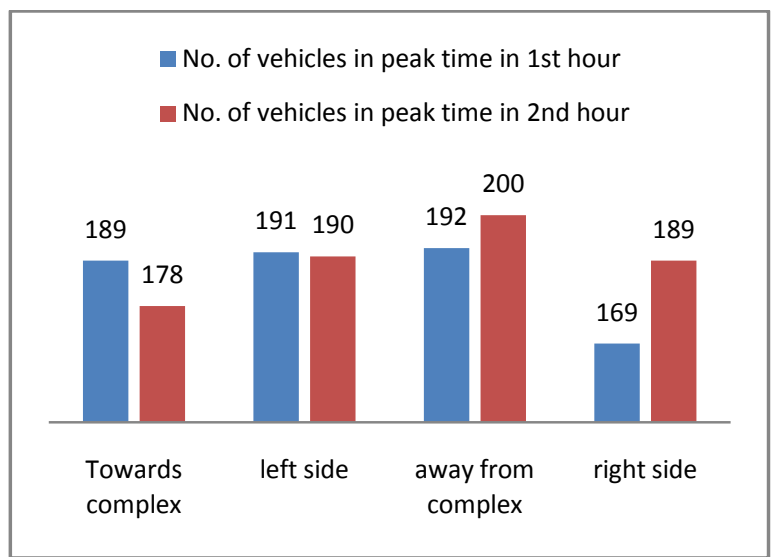

Fig-4: No. of Vehicles in Evening Peak Hours

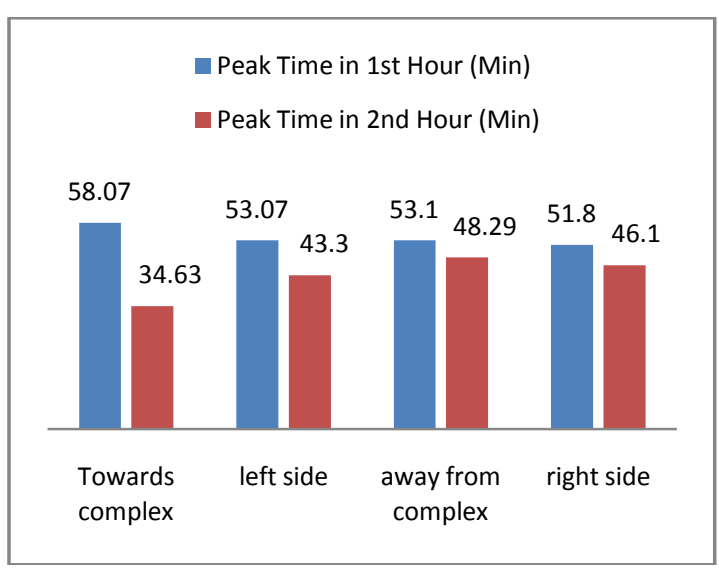

Fig-5: Hourly variations of Time (Min) 
Table-3: Hourly Traffic in Morning Peak Hours at Kancharpalem Junction

\begin{tabular}{|l|l|l|l|l|}
\hline \multirow{2}{*}{ Conflict } & \multicolumn{2}{|l|}{ No. of Vehicles } & \multicolumn{2}{l|}{$\begin{array}{l}\text { Maximum } \\
\text { Capacity }\end{array}$} \\
\cline { 2 - 5 } & $\begin{array}{l}\text { 1st } \\
\text { Hour }\end{array}$ & $\begin{array}{l}\text { 2nd } \\
\text { Hour }\end{array}$ & $\begin{array}{l}\text { 1st } \\
\text { Hour }\end{array}$ & $\begin{array}{l}\text { 2nd } \\
\text { Hour }\end{array}$ \\
\hline Left Side & 197 & 196 & 32 & 31.53 \\
\hline Towards Convent & 203 & 205 & 28.4 & 58.18 \\
\hline $\begin{array}{l}\text { Away from } \\
\text { Convent }\end{array}$ & 183 & 191 & 58.07 & 52.98 \\
\hline Right Side & 199 & 192 & 58.07 & 55.32 \\
\hline
\end{tabular}

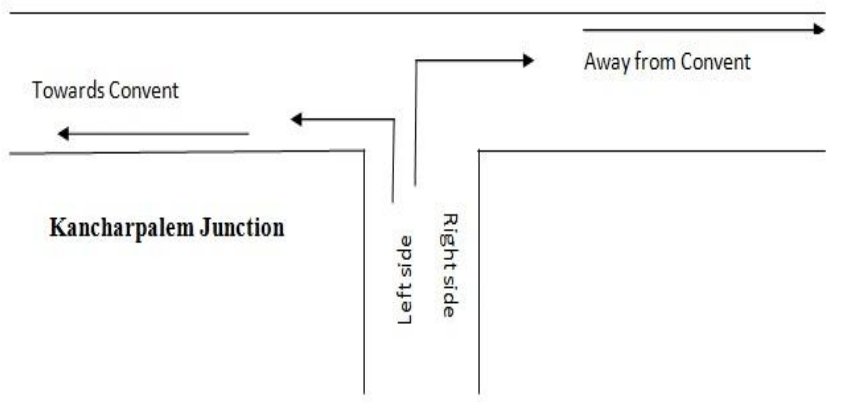

Fig-6: Kancharpalem Junction

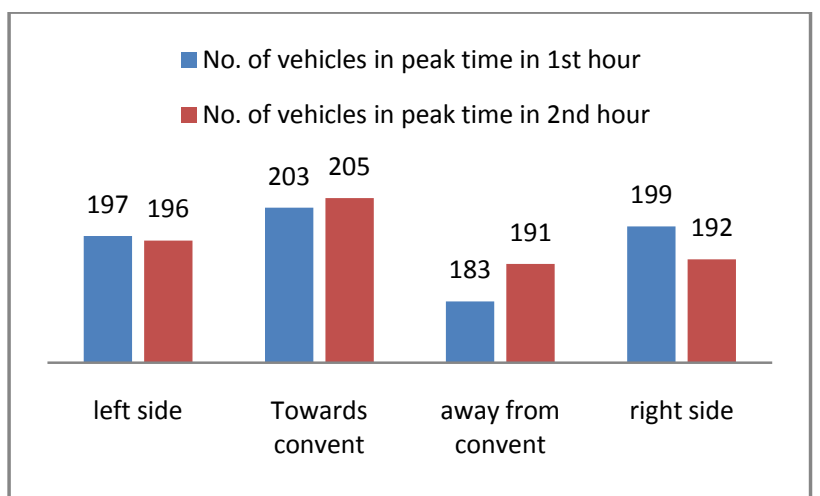

Fig-7: No. of Vehicles in Peak Hours

- Peak Time in 1st Hour (Min) $n$ Peak Time in 2nd Hour (Min)

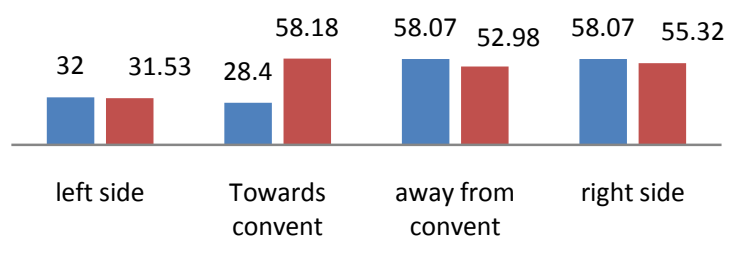

Fig-8: Hourly variations of Time (Min)

Table-4: Hourly Traffic in Evening Peak Hours at Kancharpalem Junction

\begin{tabular}{|l|l|l|l|l|}
\hline \multirow{2}{*}{ Conflict } & \multicolumn{2}{|l|}{ No. of Vehicles } & \multicolumn{2}{l|}{$\begin{array}{l}\text { Maximum } \\
\text { Capacity }\end{array}$} \\
\cline { 2 - 5 } & $\begin{array}{l}\text { 1st } \\
\text { Hour }\end{array}$ & $\begin{array}{l}\text { 2nd } \\
\text { Hour }\end{array}$ & $\begin{array}{l}\text { 1st } \\
\text { Hour }\end{array}$ & $\begin{array}{l}\text { 2nd } \\
\text { Hour }\end{array}$ \\
\hline Left Side & 198 & 212 & 38.3 & 31.57 \\
\hline
\end{tabular}

\begin{tabular}{|l|l|l|l|l|}
\hline Towards Convent & 192 & 196 & 38.3 & 33.63 \\
\hline $\begin{array}{l}\text { Away from } \\
\text { Convent }\end{array}$ & 201 & 209 & 46.02 & 44.62 \\
\hline Right Side & 197 & 207 & 39.7 & 37.23 \\
\hline
\end{tabular}

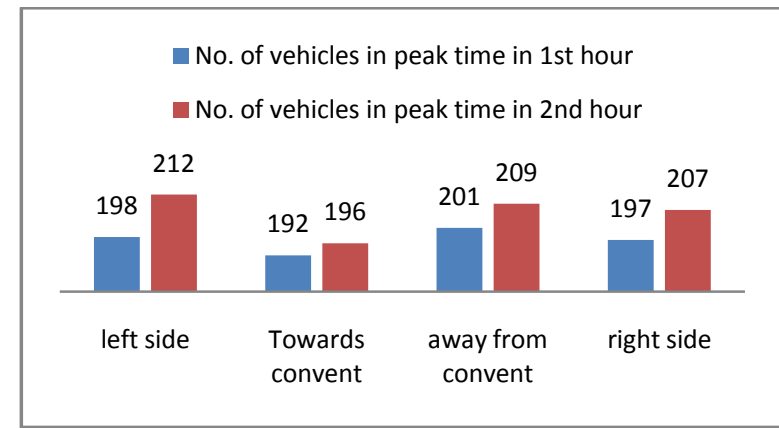

Fig-9: No. of Vehicles in Evening Peak Hours

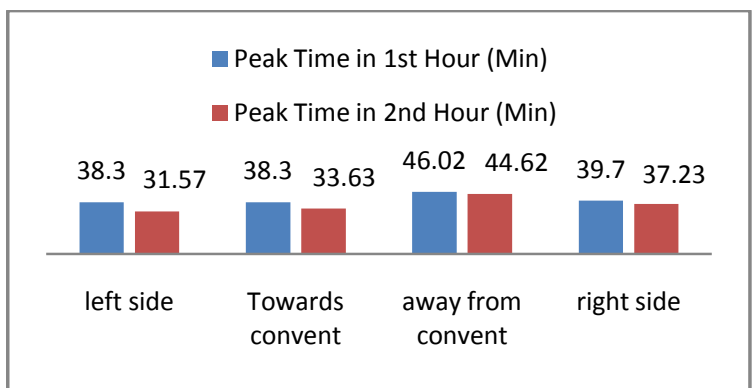

Fig-10: Hourly variations of Time (Min)

Table-5: Hourly Traffic in Morning Peak Hours at Gnanapuram Junction

\begin{tabular}{|l|l|l|l|l|}
\hline \multirow{2}{*}{ Conflict } & \multicolumn{2}{|l|}{ No. of Vehicles } & \multicolumn{2}{l|}{$\begin{array}{l}\text { Maximum } \\
\text { Capacity }\end{array}$} \\
\cline { 2 - 5 } & $\begin{array}{l}\text { 1st } \\
\text { Hour }\end{array}$ & $\begin{array}{l}\text { 2nd } \\
\text { Hour }\end{array}$ & $\begin{array}{l}\text { 1st } \\
\text { Hour }\end{array}$ & $\begin{array}{l}\text { 2nd } \\
\text { Hour }\end{array}$ \\
\hline $\begin{array}{l}\text { Towards } \\
\text { Dondaparthy }\end{array}$ & 200 & 206 & 42.45 & 45.67 \\
\hline Left Side from & 206 & 205 & 54.03 & 56.27 \\
\hline $\begin{array}{l}\text { Away } \\
\text { Dondaparthy }\end{array}$ & 193 & 206 & 39.02 & 29.88 \\
\hline Right Side & 199 & 203 & 59.41 & 48.64 \\
\hline
\end{tabular}

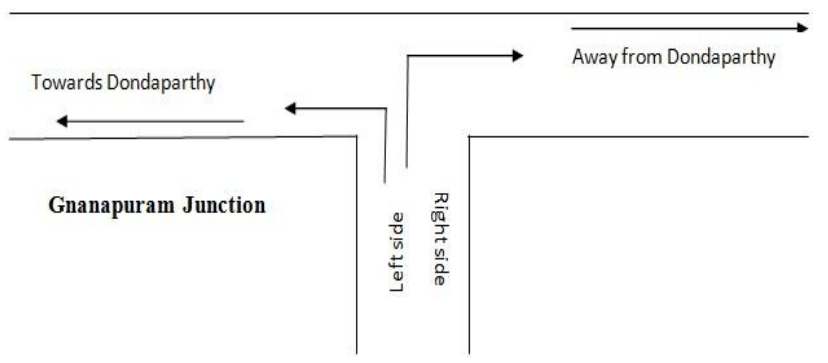

Fig-11: Gnanapuram Junction 


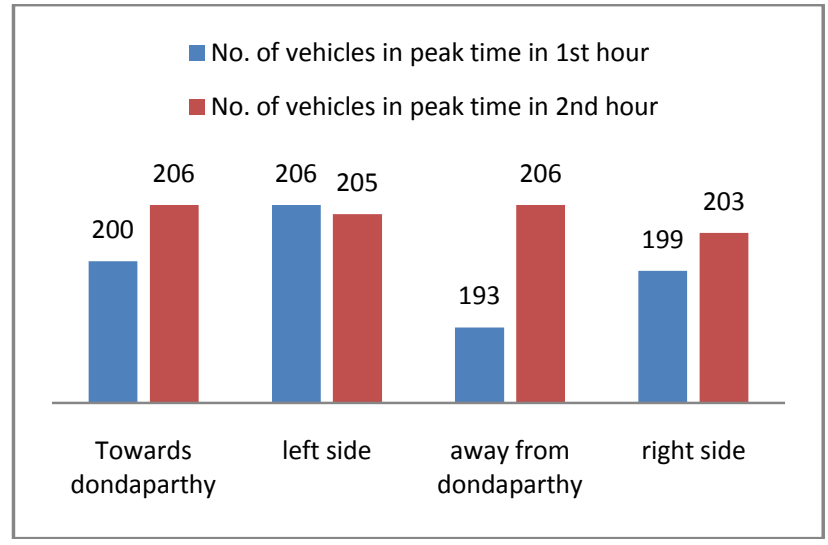

Fig-12: No. of Vehicles in Morning Peak Hours

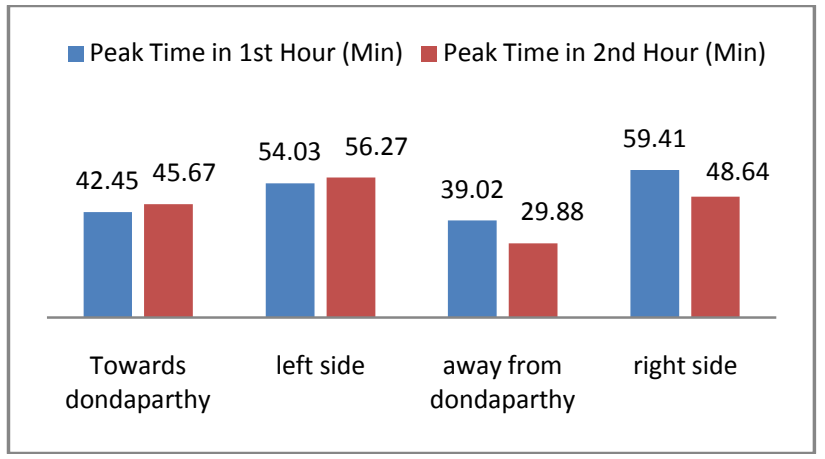

Fig-13: Hourly variations of Time (Min)

Table-6: Hourly Traffic in Evening Peak Hours at Gnanapuram Junction

\begin{tabular}{|l|l|l|l|l|}
\hline \multirow{2}{*}{ Conflict } & \multicolumn{2}{|l|}{$\begin{array}{l}\text { No. of } \\
\text { Vehicles }\end{array}$} & \multicolumn{2}{l|}{$\begin{array}{l}\text { Maximum } \\
\text { Capacity }\end{array}$} \\
\cline { 2 - 6 } & $\begin{array}{l}\text { 1st } \\
\text { Hour }\end{array}$ & $\begin{array}{l}\text { 2nd } \\
\text { Hour }\end{array}$ & $\begin{array}{l}\text { 1st } \\
\text { Hour }\end{array}$ & $\begin{array}{l}\text { 2nd } \\
\text { Hour }\end{array}$ \\
\hline $\begin{array}{l}\text { Towards } \\
\text { Dondaparthy }\end{array}$ & 193 & 196 & 54.09 & 57.8 \\
\hline Left Side from & 197 & 204 & 43.28 & 58.75 \\
\hline $\begin{array}{l}\text { Away } \\
\text { Dondaparthy }\end{array}$ & 211 & 185 & 48.1 & 38.31 \\
\hline Right Side & 198 & 195 & 60.14 & 38.31 \\
\hline
\end{tabular}

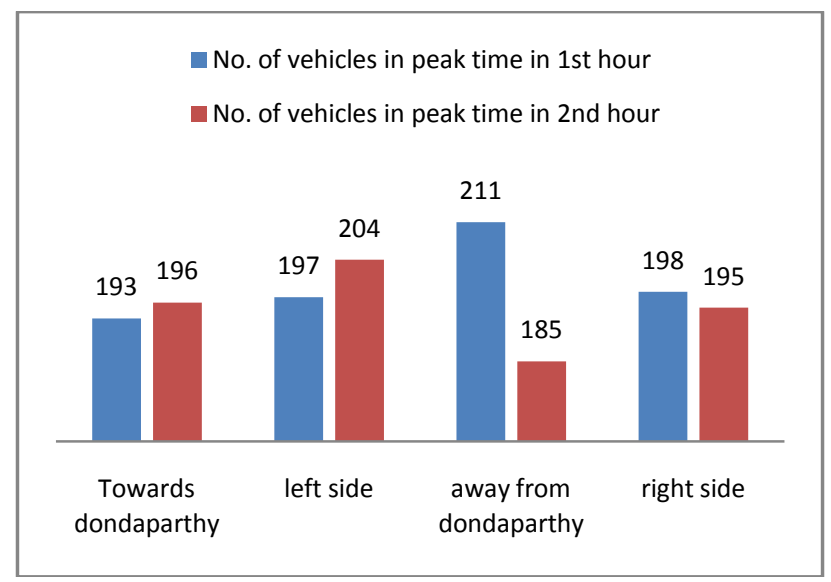

Fig-14: No. of Vehicles in Evening Peak Hours

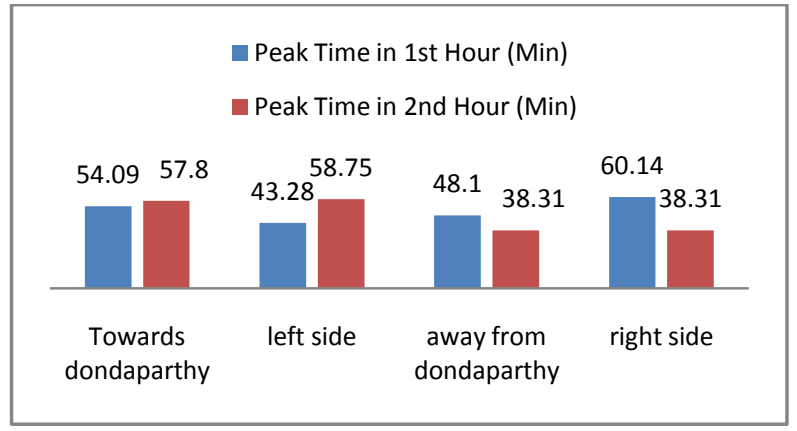

Fig-15: Hourly variations of Time (Min)

\section{CONCLUSIONS}

1. Conflict technique is a simple method for calculating capacity of unsignalized intersections.

2. The modified Tanner's formula was found to be the most suitable model.

3. The input data like Volume, Flow, and Capacity of each type of vehicle can be measured from the field where as for gap acceptance models the input parameters i.e., Critical gap and Follow up time (tc, tf) are measured.

4. By Comparing all the $3 \mathrm{~T}$-intersections are:

- The study area Kancharpalem has shown the mixed traffic conditions.

- The study area Gnanapuram has shown the Major Stream.

- The study area Urvasi has shown the Major Stream.

5. The signal should be provide at Kancharpalem and Gnanapuram Junctions.

\section{REFERENCES}

[1] A.Aldian, Michael A.P.Taylor "Selectig Priority Junction Traffic models to determine U-turn Capacity at median opening".Proceedings of the Eastem Asia Society for Transportation Studies. Vol.3. No.2, Octobcr, 2001.

[2] Ian C. Espada(1), Takashi Nakatsuji(2) and Yordphol Tanaboriboon(3) "A Discharge Capacity Formula for Priority T-Intersection and its Application to Macroscopic Simulation of Urban Networks". J. Infrastructure Plan and Man., JSCE, No. 695/IV-54, 177-186, January 2002.

[3] Ning WU “A Universal Procedure for Capacity determination at Unsignalized (priority-controlled) Intersections" Institute for Transportation and Traffic Engineering, Ruhr University, 44780 Germany, 21st December 1999.

[4] Tian et al (1999), "Implementing the Maximum Likelihood Methodology to measure a driver's critical gap", Transportation Research, Part A, No.33 (1999), pp 187-197.

[5] Unsignalized Intersections Chapter-17 "Highway Capacity Manual 2000".

[6] Wan Hashim Wan Ibrahim "Estimating Critical Gap Acceptance for unsignalized T-intersection under mixed traffic flow condition" Eastern Asia Society for Transportation Studies, Vol.6, 2007. 
[7] Werner Brilon, Ning Wu, Kerstin Lemke, (1996),

"Capacity at unsignalized two-stage priority intersections", Transportation Research Part A 33, pp: 275-289.

[8] Werner Brilon, Rod J. Troutbeck and Ralph Koenig "Useful Estimation Procedures for Critical Gaps" 3rd International Symposium on Intersections without Traffic Signals, Portland Oregon, PP. 71-87, July 1997. 